\title{
TOWARDS STRATEGIC SELF-REGULATION IN SECOND/FOREIGN LANGUAGE LEARNING. PART III. LEARNER STRATEGY CHOICES AND LANGUAGE LEARNING SUCCESS
}

\section{STRATEGICZNA SAMOREGULACJA W NAUCE JEZZYKA DRUGIEGO/OBCEGO. CZĘŚĆ III. WYBÓR STRATEGII PRZEZ UCZNIA A SUKCES W NAUCE}

\author{
Małgorzata Dąbrowska1 ${ }^{1(\mathrm{~A}, \mathrm{~B}, \mathrm{C}, \mathrm{D}, \mathrm{E}, \mathrm{F}, \mathrm{G})}$
}

\author{
${ }^{1}$ Państwowa Szkoła Wyższa im. Papieża Jana Pawła II w Białej Podlaskiej, \\ Wydział Nauk o Zdrowiu i Nauk Społecznych, Katedra Nauk Humanistycznych i Społecznych, Zakład Neofilologii
}

Dąbrowska, M. (2018). Towards strategic self-regulation in second/foreign language learning. Part III. Learner strategy choices and language learning success. Rozprawy Społeczne, 12(1), 29-39. https://doi.org/10.29316/rs.2018.04

Wkład autorów:

A. Zaplanowanie badań

B. Zebranie danych

C. Dane - analiza i statystyki

D. Interpretacja danych

E. Przygotowanie artykułu

F. Wyszukiwanie i analiza

literatury

G. Zebranie funduszy
Tabele: 1

Ryciny: 1

Literatura: 34

Otrzymano: lipiec 2016

Zaakceptowano: listopad 2016

\section{Summary}

Introduction. The main aim of this series of three articles is to explore the question of what it is that makes 'good' language learners, what individual factors can influence the learner's success in foreign language learning, and what teachers and learners can learn from those who succeed in this complex task. In Part I., the author reviews a number of research studies on the 'Good Language Learner' issue; she also attempts to summarize the main characteristics, strategies, and behaviours of successful and unsuccessful learners. Part II. presents an overview of studies focused on the role of selected individual differences and shows how the variables may influence the process and outcomes of language learning; it also indicates which strategies and behaviours of 'good' learners can be taught and learnt in the classroom. In Part III., the author explores the issue further and presents the results of her empirical studies aimed at identifying the features and strategies of both successful students of English as a foreign language and learners with lower achievements.

Material and methods. A number of formal structured pen-and-paper questionnaires, oral surveys and learner diaries were employed to diagnose the participants' personality traits, learning preferences and patterns of strategy use.

Results. The results of the research indicate that 'good' and less efficient learners tend to use strategies differently.

Conclusions. The pedagogical implications for L2 teaching and learning discussed in the series are closely related to the ideas of strategies-based and styles-and-strategies-based instruction in language education, self-regulated or autonomous language learning, and continued lifelong learning.

Keywords: 'good' language learners, 'less successful' language learners, individual differences, learning strategies, self-regulation in learning

\section{Streszczenie}

Wstęp. Niniejszy cykl trzech artykułów poświęcony jest zagadnieniu tzw. 'dobrego' ucznia języka obcego, zwiazkom pomiędzy wybranymi czynnikami indywidualnymi a sukcesem w nauce oraz próbie odpowiedzi na pytanie, czego możemy nauczyć się od uczących się języków obcych, którzy odnoszą sukces. W Cześci I. autorka dokonuje przeglądu badań cech, strategii i zachowań 'dobrego' ucznia oraz przedstawia charakterystyke uczniów o wysokich i niższych poziomach osiagnieć. Część II. poświęcona jest roli wybranych czynników indywidualnych oraz omówieniu badań wskazujących na to, w jaki sposób mogą one wpływać na przebieg i wyniki nauki języka obcego oraz jakich zachowań i strategii 'dobrych' uczniów można nauczać i nauczyć się w klasie szkolnej. W Cześci III. autorka prezentuje wyniki własnych badań empirycznych mających na celu identyfikację cech i strategii uczących się o zróżnicowanych poziomach osiągnięć $w$ nauce języka angielskiego jako obcego $w$ warunkach szkolnych. Materiał i metody. W badaniach wykorzystano narzedzia do diagnozy wybranych cech osobowości, stylów poznawczych oraz indywidualnych preferencji i wzorców aktywacji strategii uczenia się. Wyniki. Wyniki badań wskazują na istnienie różnic w stosowaniu strategii przez 'dobrych' i mniej skutecznych uczniów.

Wnioski. Implikacje pedagogiczne zagadnień omawianych w tej serii artykułów powiązane są $\mathrm{z}$ ideą instrukcji strategicznej w edukacji językowej, samoregulacji i autonomii w nauce oraz umiejętnościom niezbędnym do kontynuacji uczenia się przez całe życie.

Słowa kluczowe: 'dobry’ uczeń języka obcego, uczeń o niższych poziomach osiągnięć, różnice indywidualne, strategie uczenia sie, samoregulacja w nauce

Adres korespondencyjny: Małgorzata Dąbrowska, Państwowa Szkoła Wyższa im. Papieża Jana Pawła II w Białej Podlaskiej, ul. Sidorska 95/97, 21-500 Biała Podlaska e-mail:malda@vp.pl, tel.508159617

Copyright by: Państwowa Szkoła Wyższa im. Papieża Jana Pawła II w Białej Podlaskiej, Małgorzata Dąbrowska

Czasopismo Open Access, wszystkie artykuły udostępniane są na mocy licencji Creative Commons Uznanie autorstwa-użycie niekomercyjne-na tych samych warunkach 4.0 Międzynarodowe (CC BY-NC-SA 4.0, http://creativecommons.org/licenses/by-nc-sa/4.0/). 


\section{Introduction}

Numerous research studies, including those presented in Part I. and Part II. of this series of articles, have been devoted to thorough exploration of the 'Good Language Learner' (GLL) issue. In particular, as evidenced in these articles, many researchers have been interested in investigating the features and behaviours which characterize learners who succeed in the second/foreign language learning venture. In fact, the research on the topic has produced a number of overlapping sets of learner individual traits as well as strategies for language learning and language use; this proves that good, or successful, learners are certainly far from being passive in the learning process. The studies have also provided rich and useful insights into the nature of second/foreign language learning processes, and enlarged the body of knowledge about strategic decisions, moves, and behaviours of those who can be considered (more) competent language learners. Thus, as indicated in Part I., they have contributed to the development of research directed first at identifying, characterizing, defining, and classifying strategies used by 'good' language learners, and then integrating or incorporating a variety of learner strategies into regular language learning in purposeful, conscious, and directed ways.

In this article, the author wishes to present two GLL- and strategy-related research studies which she conducted among adult learners of English as a foreign language at advanced levels of proficiency (i.e. CEFR level C1). The results of the studies may contribute to what we know about 'good' language learners and appear to bear vital pedagogical implications as to what we can learn from those who succeed. The teaching and learning implications also concern the question of whether it seems desirable and advisable to conduct and participate in purposeful and directed strategy training aimed at helping less successful learners learn more effectively thanks to deliberate activation of appropriate learning strategies which are used by 'good' language learners. Thus, they may be of help not only to language teachers working with adult second/foreign language learners, but, which seems equally essential, to language learners. As many experts emphasize, lifelong learning abilities, such as the ability to set long-term goals and shortterm objectives, organize, manage, monitor, control, and evaluate one's own learning independently and self-reliantly, have become indispensable in the repertoire of human life-skills in today's world. In fact, its dynamically changing economic realities, growing social mobility, and diversifying job market requirements in increasingly multicultural and multilingual communities create a need for workers, and learners, able to acquire and develop new knowledge, skills, and qualifications in a continued, self-regulated, and life-long learning process (Wilczyńska, 2002; Janowska, 2003; Dąbrowska, 2011).

\section{Learner strategy choices and the GLL issue: two empirical studies}

\section{Study A and Study B: the research design and procedures}

Study A. The first research study the author wishes to present in this article was a part of a larger, two-stage project conducted in the English Department of the Higher Vocational State School in Biała Podlaska. The whole project extended over a full academic year. It began in October 2003 and was completed in June 2004. The author's principal goal in designing the first, diagnostic part of the project was to gain deeper insights into quantitative and qualitative aspects of adult foreign language learners' learning processes and strategy activation. The main aim of the second, experimental stage was to investigate the results of a purposeful, longterm, and completely-informed strategy training scheme on the participants' patterns of strategy use. In fact, the author's intention was to explore the issue of trainability of adult learners in L2 learning strategies and examine possibilities of conscious strategy development at more advanced levels of language proficiency. The second part was designed on the basis of the results obtained in the preceding diagnostic stage, which allowed the author to extend her knowledge of the subjects and helped to raise the students' self-awareness in terms of selected personality traits, cognitive/learning styles, learning strategies, and individual learning preferences (for the detailed description of each part of the project as well as presentation and discussion of the outcomes obtained within each stage see Dąbrowska, 2008).

Study B. The second study the author wants to briefly refer to was an initial part of a regular course in Autonomy and Strategy Instruction in Children's Language Education conducted by the author within the Glottodidactic Module for future language teachers doing their third year of studies in the same teacher training institution, that is, the English Department of Pope John II State School of Higher Education in Biała Podlaska (the official name of the school was formally changed soon after Study A was completed). The course lasted a full academic summer semester, from February 2015 till June 2015. The main goal of the research done at the beginning of the course was to investigate individual patterns of learning strategy use by the subjects invited to participate in the project, and analyze and compare the strategies used by more and less successful students in the group. At the beginning of the course, the students were acquainted with selected articles and readings from the literature on individual differences- and strategy-related issues, participated in class discussions of these topics, talked about themselves as foreign language learners, exchanged ideas as to how they learnt foreign languages and which personal approaches, strategies, or techniques they considered effective and ineffective. In this way, 
similarly to Study A, the author wanted to enrich her knowledge of the subjects and help the participants raise their own self-knowledge, or self-awareness; she also wished to help the students further develop their knowledge of selected personality traits, learning preferences, cognitive/learning styles, strategies for language learning and use, and consider their influences on the process and outcomes of second/ foreign language learning.

It must be noted that designing and conducting the first, full-academic-year-long project, and later semester-long courses on learner autonomy and independent learning strategies, the author intended to inspire the subjects to invest (more) time and personal effort in further self-exploration, and to seek both theoretical information and practical solutions concerning appropriate and individually suitable strategic language learning behaviours. The author also wished to encourage the learners to search for, experiment with, and practise new and varied learning strategies regularly, in and beyond the school. It seems worth adding that both the subjects in Sample A and in Sample B were asked to write their own personal journals which were also supposed to encourage the students to systematically reflect on their language learning experiences and look for ways of overcoming learning problems.

\section{The samples}

The subjects in Study A were 42 Polish learners of English as a foreign language at the B2/C1 proficiency level. There were 34 females and 8 males at the ages of 20-35, formally divided into two study groups of 22 and 20 students. The subjects invited to participate in Study B were 15 Polish learners of English at the C1 proficiency level. There were 12 females and 3 males at the ages of 22-23, studying English and other subjects as one student group.

Apart from the age range, which was much wider in Sample A, the participants in Study A, and similarly in Study B, shared a number of characteristics. To begin with, they attended the same educational institution and at the time of the research they were doing the same year in English Studies (BA in English Philology); thus, they were at similar stages of language development and shared similar learning experiences. Semi-structured surveys conducted at the beginning of both studies revealed that they also shared similar cultural, social, and educational backgrounds as well as the mother tongue; the students in both groups were born, raised and educated in Poland. Basically, they studied English in formal school settings, but within the course of their education, the majority of the subjects in both groups had the experience of learning English in private courses. It must be added that the subjects in both studies did not have very extensive experience of travelling abroad and learning other foreign languages in other countries. In fact, the majority of over $60 \%$ studied two foreign languages, over $16 \%$ in Study A and twice as many around 31\% in Study B learnt three languages, while
$12 \%$ in Study A learnt four languages. Russian, German, and French were the predominant languages studied in addition to English. All the students had contacts with English, English-speaking countries and their cultures either via the Internet, television, radio, or press, and occasionally meeting foreigners. Interestingly, 81\% of the students in Study A complained about having few possibilities to use English to communicate out of school, in real-life situations, while 19\% purposefully sought regular contacts with other speakers of English by writing letters and exchanging e-mails. Last but not least, it must be stressed that only $17 \%$ of the subjects in Study A and almost 44\% in Study B declared that they met regularly, either at the school's premises or beyond the school, to practise English together.

What seems particularly important to the topic of this article is the fact that the majority of the students in both samples tended to be teacher-dependent. Especially, the subjects in Study A seemed highly teacher-dependent, which they repeatedly admitted during oral interviews and class discussions, confirming the author's observations; moreover, in their written language learning diaries all the subjects in Study A frequently emphasized their strong preferences for learning under teacher control and guidance rather than on their own or with friends, in groups or pairs, both in and beyond the school. Thus, they appeared to lack appropriate, or properly developed, strategies that could help them make foreign language learning a more independent or autonomous venture. Oral interviews and class discussions revealed that the tendency was weaker among the subjects in Study B; in fact, 93\% of the students admitted that they liked learning with their friends and cooperating in pairs and/or groups, even though they still tended to stress their preferences for the teacher's control of their learning.

\section{The objectives of the studies and research questions}

Taking into consideration the topic of this article and the common objectives of Study A and Study B, the author sought to:

(1) identify 'good' language learners and 'less successful' students in both samples ${ }^{1}$;

(2) examine individual characteristics and patterns of strategy use in each of the two learner subgroups;

(3) examine whether and, if so, which individual characteristics might be associated with more successful and which with less effective foreign language learning;

(4) identify and compare categories and frequencies of strategy implementation by 'good' and 'less successful' adult language learners, and in this way see whether better results could be attributed to learner choices of particular strategy groups and frequencies of their employment.

\footnotetext{
'Successful' and 'less successful' language learning was operationalized as the learners' average grades obtained in their Practical English classes, where the average grades of 4, 4+ and 5 were equated with 'successful' learning.
} 
Thus, the above specified common research objectives gave rise to the following research questions in both studies, Study A and Study B:

Question 1. Which individual features may be claimed to link to more successful language learning and which may be associated with less effective learning and its results?

Question 2. Are there any differences between patterns (i.e. categories and frequencies) of strategy use by 'good' and 'less successful' foreign language learners? If so, what is their nature and can better learning results be attributed to certain patterns of learner strategy use?

\section{Methods and tools of data collection}

In order to guide and help the participants in both studies, Study A and Study B, better understand themselves as foreign language learners, as well as collect the needed data, at the beginning of each project the students were asked to diagnose selected personality traits, learning styles, left-/right-brain hemisphere dominance, and patterns of strategy activation with the use of formal structured paperand-pencil questionnaires. In this article, the author presents the results obtained through the application of the following individual-factors-related written tests administered in both studies: Torrance's 1987 Extroversion/Introversion Test (see Brown, 1994, p. 196) and The Right/Left Brain Dominance Test (see Brown, 1994, p. 197). Additionally, the learners' visual, auditory, and/or kinesthetic modes of learning were investigated with the use of the Learning Styles questionnaire adopted from Tanner and Green (1998, p. 90; cf. Reid, 1995) ${ }^{2}$, since all these instruments allow students to expand their self-knowledge and they are easy to access and administer by teachers and learners alike.

As most learning strategies are learner internal or private mental operations, which are difficult, and sometimes impossible, to identify by means of observational methods, the main tool applied to investigate the students' observable and unobservable strategy useand assess frequencies of strategy activation with the task of learning English as a foreign language was a paper-and-pencil survey, the Strategy Inventory for Language Learning (SILL), a Likert-scaled, 50-item measure divided into six parts, each corresponding to one of Oxford's (1990) six groups of learning strategies. The SILL's items are based on her typology and cover: (A) Memory Strategies (Remembering More Effectively, items 1-9); (B) Cognitive Strategies (Using Your Mental Processes, items 10-23); (C) Compensation Strategies (Compensating for Missing Knowledge, items 24-29); (D)

\footnotetext{
In the 2003/2004 project the author employed also a structured written survey in which the subjects were asked to answer 'yes' or 'no' to a series of questions, grouped into 13 subsets related to the following individual factors: extroversion/introversion, inhibition, anxiety, risk-taking, empathy, sensitivity to rejection, tolerance of ambiguity, field independence/dependence, and reflectivity/impulsivity (for details see Dąbrowska, 2008).
}

Metacognitive Strategies (Organizing and Evaluating Your Learning, items 30-38); (E) Affective Strategies (Managing Your Emotions, items 39-44); and (F) Social Strategies (Learning with Others, items 45-50). The first three strategy groups belong to the category of direct strategies; the other groups are indirect strategies (see Oxford 1990, pp. 293-300; Version for Speakers of Other Languages Learning English 7.0).

The students were also asked to judge their own qualities considering the features, strategies, and behaviours of 'Good Language Learners'. Therefore, they were requested to respond to a set of statements based on Naiman, Frohlich, Stern and Todesco's (1978) study and fill in the structured paper-andpencil Questionnaire for a Good Language Learner (see Wenden, 1991, p. 123). It must be added that the author used Wenden's suggestions and all tasks devoted to the GLL issue; however, the procedures leading to learner self-diagnosis were reversed to help the subjects activate their current self-knowledge, self-evaluate and answer the question of whether they thought they could be classified as GLLs or not. To make the task more manageable and raise the validity and reliability of the students' self-judgments, they were asked to read $A$ definition of a good language learner, work on the Comprehension guide, discuss GLLs' behaviours and techniques, and share their own answers in pairs and later as a whole group (see Wenden, 1991, pp. 121-122). Finally, the students received the forms of the written questionnaire; then, once again they reflected upon their own characteristics individually, and made final decisions on whether they could consider themselves 'Good Language Learners' or not. In this way, the selfdeclared GLLs were identified in the samples.

In order to investigate the GLL issue (that is, the GLLs' traits and strategy use) thoroughly, the author asked the students to report on their last semesterfinal grades in the Practical English (PE) classes of listening, speaking, reading, and writing. The results were used to calculate the average arithmetic PE grades for each individual student, and the mean grade of 4.0 was established as the criterion applied by the author to classify the subjects as 'good' language learners (the mean grade: 4.0 and above) and 'less successful' language learners (the mean grade: below 4.0). The results gathered in both GLL groups (i.e. the self-declared one and the mean PE grade-related one) were analyzed quantitatively and qualitatively.

Other information necessary to conduct the studies was collected with the application of a self-prepared background factors questionnaire, with selected items adopted from Abraham and Vann's (1987, pp. 99-101) Instruments Used for Assessing Background Factors as well as selfprepared and adapted checklists, semi-structured informal interviews, group discussions, learner self-revelatory techniques, L2 learning diaries, and teacher observation. 


\section{Results}

Study A. Analyses of the results obtained through the application of the above described instruments showed that one third (33.33\%) of the subjects in the sample were classified as 'good' language learners (i.e. those who obtained the mean grade of 4.0 or above in all their Practical English classes) and twice as many (66.66\%) as 'less successful' language learners. Interestingly, two thirds (64.28\%) declared themselves to be GLLs. This may indicate that, in the students' opinion, school grades were neither the only nor the most important indicators of language learning success. Calculations of average PE grades produced the highest score of 4.03 in the GLL group, the mean of 3.70 among the self-declared GLLs, and the average of 3.25 in the 'less successful' group. To compare, the whole sample's average grade was $3.52^{3}$.

As far as Question 1 is concerned, referring to the average PE grades obtained by each of the individualfactor-related student subgroups, it can be noticed that extroversion (3.63) (as well as impulsivity, lack of anxiety and risk-taking) and left-brain dominance (3.55) linked to more successful L2 learning in formal academic settings (i.e. the results were higher than the whole group's average). Consequently, introversion (3.33) (as well as risk-avoidance, inhibition, and reflectivity), right-brain and no particular left-/rightbrain dominance (3.5) were associated with less successful language learning, which produced the results lower than the group's average grade. In fact, these outcomes are in agreement with many findings reported in the literature on the topic, even though the identified differences were not significant.

The answer to Question 2 demanded quantitative and qualitative analyses involving comparisons of categories and frequencies of strategy employment by the 'good' language learners (GLLs) and the 'less successful' learners in the sample. To start with, the results of the SILL survey revealed that the GLLS utilized Oxford's learning strategies more frequently (i.e. with the overall average frequency of strategy use of 3.32 on Oxford's SILL scale) than the 'less successful' students whose overall average frequency of strategy application was 3.07; however, both results fell within the upper medium, or 'sometimes used', range of strategy frequency. Thus, they did not differ strikingly (see: Table 1 as well as Figure 1 with Oxford's Key to Understanding the Average presented at the end of this section).

As far as the use of particular strategy categories and the frequencies of their activation by the GLLS and the 'less successful' learners are concerned, the patterns detected differed. In fact, the GLL group tended to rely on metacognitive strategies most (i.e. their average frequency of strategy use within this strategy category was 3.80), which placed them within the lower high, or 'usually used', rate of strategy occurrence. They also activated compensation and

\footnotetext{
This average grade was established as a reference point in judging the degrees of the subgroups' learning success.
}

cognitive strategies in a similar way (i.e. with the average strategy frequency of 3.70). They turned to memory strategies less often, with the upper medium frequency (3.22), and applied affective (2.86) and social (2.65) strategies with the lower medium rates of strategy use. Generally, the GLLs utilized each of Oxford's six strategy groups more frequently than the 'less successful' learners. In fact, the 'less successful' learners employed compensation strategies most frequently (3.50), though not as frequently as the GLLs, and used metacognitive (3.35) and cognitive (3.25) strategies even less often. The 'less successful' learners also tended to resort to memory strategies (3.07) not as frequently as the GLLs; nevertheless, the four categories were activated with the upper medium frequencies of strategy application. It must be noted that both student subgroups applied affective strategies in a similar manner; however, the 'less successful' subjects resorted to these strategies less often (2.76) than the GLLs. Finally, the subjects neglected social strategies and generally did not tend to employ them (2.48).

In fact, considerable discrepancies in the frequencies of strategy use by the GLL subgroup and the 'less successful' students were found in the subgroups' employment of metacognitive and cognitive strategies $(0.45)$, while the least noticeable differences were detected in their use of affective (0.1), memory (0.15), and compensation (0.2) strategies. It seems worth noting that, as the standard deviation scores indicated, the GLLs constituted a far more homogeneous group of strategy users $(S D=0.173)$ than the 'less successful' students $(S D=0.405)$. Additionally, the GLLs used memory strategies most similarly $(S D=0.261)$, but resorted to affective strategies in the most heterogeneous way $(S D=0.67)$. The 'less successful' learners also employed memory strategies most uniformly, though markedly more diversely than the GLLs $(S D=0.459)$, and turned to metacognitive strategies most variably $(S D=0.613)$.

Study B. Analyses of the outcomes obtained through the administration of the same tools indicated that over half (53.33\%) of the subjects in the sample were classified as 'good' language learners and almost half (46.66\%) of them were categorized as 'less successful' language learners. Interestingly, four fifths (80\%) declared themselves to be GLLs, which seems to indicate that, similarly to the students in Study A, the subjects in Study B did not perceive school grades as the only or the most important indicator of foreign language learning success. Calculations of average PE grades produced the highest mean score of 4.37 in the GLL group, the mean of 4.07 among the self-declared GLLs, and the average of 3.51 in the 'less successful' group. To compare, the whole sample's average grade was $3.97^{4}$.

\footnotetext{
This average grade was established as a reference point in judging
} the degrees of the subgroups' learning success. 
As far as the answer to Question 1 is concerned, analyses of the average PE grades obtained by each of the individual-factor-related student subgroups showed that introversion (4.2), left-brain dominance (4.07) and no particular left-/right-brain dominance (4.0) were associated with more successful L2 learning in formal academic settings (i.e. the average grades were higher than the whole group's average). On the other hand, extroversion (3.54) and rightbrain dominance (3.75) linked to less successful language learning (i.e. the average results were lower than the group's average grade). In fact, the results revealed similar tendencies in both studies, Study A and Study B, with the exception of better average grades obtained by the introverted subjects in Study B and the extroverted students in Study A. Nevertheless, most of the results tended to be in agreement with the findings reported in the literature on the topic.

As regards the answer to Question 2, it also demanded quantitative and qualitative analyses involving comparisons of categories and frequencies of strategy employment by the 'good' language learners (GLLs) and the 'less successful' learners in the sample. To begin with, similarly to Study A, the results of the SILL survey in Study B showed that the GLLs used Oxford's learning strategies more frequently (3.50) than the 'less successful' subjects (3.24); thus, according to Oxford's scale, the GLLs' results fell within the lower high (i.e. exactly on the borderline), or the 'usually used', range of strategy frequency, while the 'less successful' learners' results were placed within the medium, or 'sometimes used', frequency range.

In regard to the activation of particular strategy categories and frequency of their use by the GLLs and the 'less successful' subjects, the patterns identified in these subgroups in Study B differed; however, interestingly, they appeared to be similar to the patterns detected in Study A in many respects. To begin with, the GLLs tended to rely on metacognitive strategies most (4.05), which - similarly to the GLLs in Study A - placed them within the high, or 'usually used', rate of strategy use; however, upon a closer analysis, they seemed to be better metacognitive strategy users than the GLLs in Study A since their score placed them within the (mid) high frequency range. Also, the GLLs in Study B applied cognitive strategies (3.8) in a similar way to the GLLs in Study A and, what is especially interesting, they used social strategies (3.70) within the (lower) high frequency of strategy occurrence; it seems worth stressing that social strategies were the least often activated by both the GLLs and the 'less successful' subgroups in Study A. Furthermore, the GLLs in Study B turned to compensation strategies (3.40) with the (upper) medium, or 'sometimes used', frequency, which was markedly lower than in study A. Finally, the (upper) medium frequency of memory strategies use (3.18) and the (lower) medium frequency of affective strategies use (2.90) were very similar to the results obtained by the GLLs in Study A. Generally, the GLLs in Study B utilized five of Oxford's six strategy groups more frequently than the 'less successful' learners in the sample, since the latter tended to activate memory strategies slightly more frequently than the former. In fact, the 'less successful' learners used metacognitive strategies (3.47) most often, within the (upper) medium frequency of strategy occurrence, though considerably less frequently than the GLLs. The also activated social strategies (3.40) within the (upper) medium frequency range, which differed remarkably from the frequency of social strategies use by their counterparts in Study A. Moreover, cognitive strategies (3.32), which were used much less often when compared to the GLLs' result, as well as compensation strategies (3.25) and memory strategies (3.23) were also utilized by the subjects within the same (upper) medium frequency range, while affective strategies (2.81) were used least often, with the (lower) medium, or 'sometimes used', frequency; this last result was, in fact, similar to the GLLs' score.

The most conspicuous discrepancies in the frequencies of strategy activation by the GLLs and by the 'less successful' students in Study B were detected in the subgroups' employment of metacognitive and cognitive strategies ( 0.58 and 0.50 respectively), which, interestingly, constituted the same pattern when compared to the results obtained in Study A. The least noticeable differences were identified in

Table 1. Comparison of average frequencies of learning strategy use by the groups of 'good' language learners and the 'less successful' language learners in Study A and in Study B (with reference to Oxford's six strategy categories)

\begin{tabular}{|c|c|c|c|c|c|c|c|c|}
\hline Study & $\begin{array}{c}\text { Learner } \\
\text { group }\end{array}$ & $\begin{array}{c}\text { Group A } \\
\text { Memory } \\
\text { strategies }\end{array}$ & $\begin{array}{c}\text { Group B } \\
\text { Cognitive } \\
\text { strategies }\end{array}$ & $\begin{array}{c}\text { Group C } \\
\text { Compensation } \\
\text { strategies }\end{array}$ & $\begin{array}{c}\text { Group D } \\
\text { Metacognitive } \\
\text { strategies }\end{array}$ & $\begin{array}{c}\text { Group E } \\
\text { Affective } \\
\text { strategies }\end{array}$ & $\begin{array}{c}\text { Group F } \\
\text { Social } \\
\text { strategies }\end{array}$ & $\begin{array}{c}\text { Overall } \\
\text { average } \\
\text { strategy } \\
\text { use }\end{array}$ \\
\hline Study A & GLLs & 3.22 & 3.70 & 3.70 & 3.80 & 2.86 & 2.65 & 3.32 \\
\hline & $\begin{array}{c}\text { Less } \\
\text { successful } \\
\text { learners }\end{array}$ & 3.07 & 3.25 & 3.50 & 3.35 & 2.76 & 2.48 & 3.07 \\
\hline Study B & GLLs & 3.18 & 3.82 & 3.40 & 4.05 & 2.90 & 3.70 & 3.50 \\
\hline & $\begin{array}{c}\text { Less } \\
\text { successful } \\
\text { learners }\end{array}$ & 3.23 & 3.32 & 3.25 & 3.47 & 2.81 & 3.40 & 3.24 \\
\hline
\end{tabular}


their employment of memory strategies $(0.05)$ and affective strategies (0.09), which also constituted a similar, though not identical, pattern. The patterns of compensation strategies use $(0.15)$ were similar as well. Last but not least, the differences in the use of social strategies (0.3) by the GLLs and the 'less successful' learners seemed most striking, also when compared to the results of the two subgroups in Study A. The results obtained in both studies are presented in Table 1 and Figure 1 below.

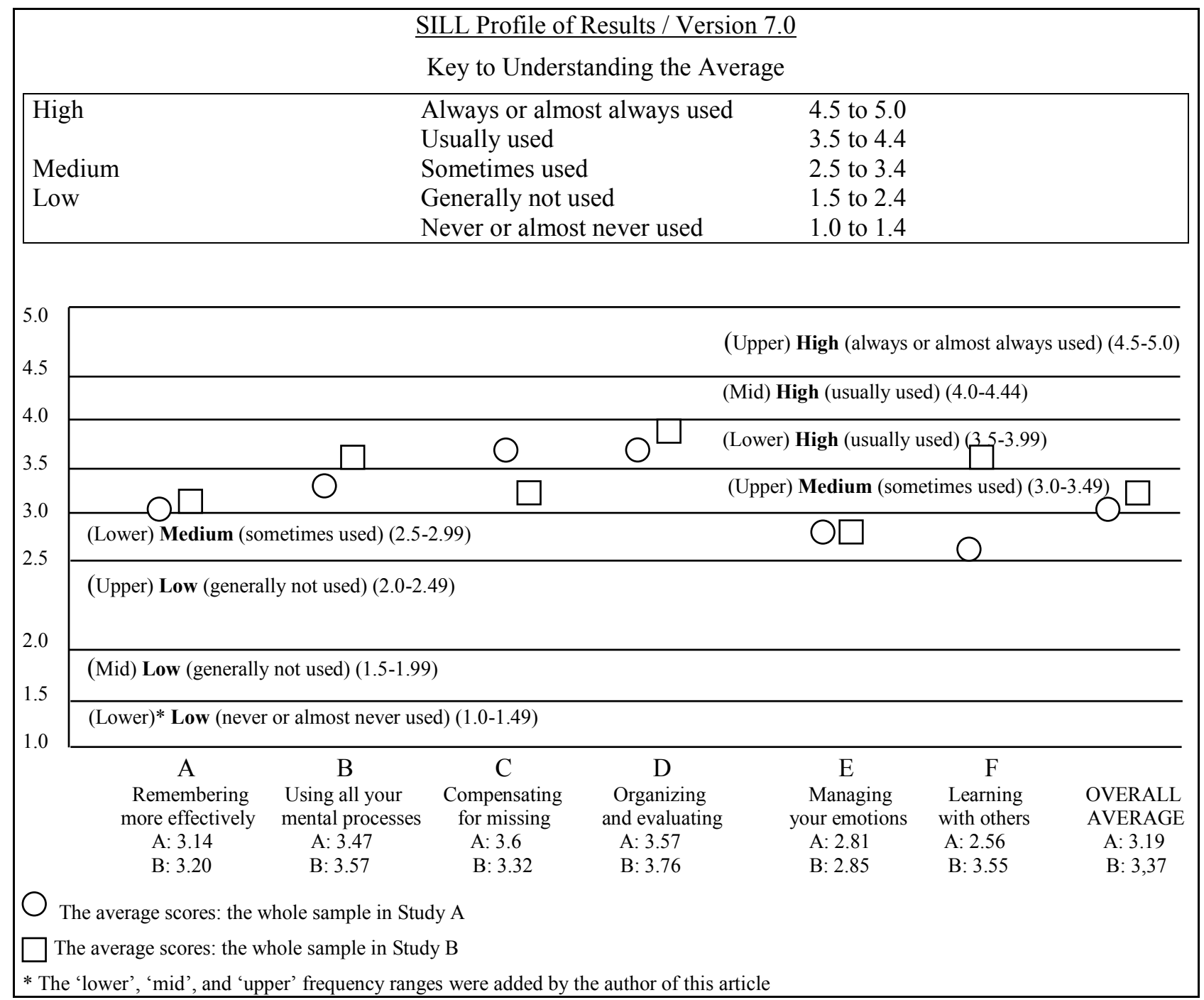

Figure 1. The whole sample's scores of average use of Oxford's six strategy groups: Study A and Study B

It seems worth adding that, as the standard deviation scores showed, the 'less successful' learners in Study B constituted a more homogeneous group of strategy users than the GLLs. In fact, taking individual scores into account, the 'less successful' subjects used metacognitive strategies in a noticeably more homogeneous manner $(S D=0.110)$ than the GLLs $(S D=0.445)$ and utilized cognitive strategies much more uniformly as well $(S D=0.286$ and $S D=0.578$ respectively). Also, they were more homogeneous users of social strategies $(S D=0.301)$ than the GLLs $(S D=0.458)$. The degree of homogeneity was closer in both subgroups in the case of compensation strategies $(S D=0.448$ and $S D=0.531$ respectively) and memory strategies $(S D=0.373$ and $S D=0.430$ respectively); however, even though the 'less successful' subjects resorted to affective strategies in a markedly more homogeneous way $(S D=0.425)$ than the GLLS $(S D=0.836)$, the results showed that the learners in the whole sample tended to activate affective strategies in the most heterogeneous, or diverse, manner. These outcomes did not seem surprising upon a closer analysis of individual scores, which revealed marked discrepancies in learner strategy use within the GLL subgroup. Thus, the student who could be considered the 'poorest' strategy user, unlike the majority in her group, tended to activate all strategy groups, except one, with considerably lower frequencies than the other subjects. Her frequency of metacognitive strategy use was 3.4 (upper medium, on the borderline), social strategies use: 2.96 (lower medium), cognitive strategies use: 2.5 (lower medium, 
on the borderline), memory and compensation strategies activation: 2.3 (low, i.e. strategies 'generally not used' in Oxford's interpretation), and affective strategy use: 4.3 (mid high, or 'usually used'). The last outcome seemed especially intriguing since only two students in this subgroup utilized affective strategies with high frequencies. Interestingly, both students were introverted; thus, it appeared that they mastered and intensively applied a wide range of affective strategies in order to cope with the affective, emotional and motivational, challenges of the language learning process. On the other hand, the frequency of strategy activation by the poorest affective strategy users in this subgroup were: 1.66 and 2.0 (low, i.e. 'generally not used'); other students did not tend to utilize affective strategies frequently as well.

\section{Discussion of the findings and final remarks}

Certain facts revealed in this investigation seem worth extra comments. First and foremost, it appears interesting that in Study A there were twice as many students with no particular left-/rightbrain hemisphere dominance in the 'less successful' subgroup than in the GLL one, although the numbers turned into percentages yielded comparable results for both subgroups, i.e. $20 \%$ and $22 \%$ of the subjects respectively. This might suggest that there is an almost identical probability that bipolar adults with no particular brain dominance could become 'good' or 'less successful' language learners. In fact, in Study B two GLLs (25\%) and two of the 'less successful' students $(28.5 \%)$ were also characterized by this feature. The results may therefore imply that a complex of other individual factors must be involved in the issue and may influence the ultimate effects of foreign language learning. Similarly, both extroverts and introverts in the two studies presented in this article belonged to either of the two learner categories, which seems to confirm intertwined impacts of other individual factors.

Secondly, as Oxford and Ehrman's (1995) research shows, and as both studies presented in this article seem to indicate, left-brain dominance, especially in classroom settings, may be related to more successful language learning, especially when combined with risk-taking, and may produce better formal results measured in terms of school grades. In fact, Oxford and Ehrman (1995) report that their lower aptitude students did not take risks and tended to be cognitively rigid, while Naiman et al. (1996) conclude that, at more advanced stages of L2 development, especially in formal settings, the cognitive factor of field independence, which is often related to leftbrain hemisphere dominance, as well as tolerance of ambiguity are the most significant predictors of success (the researchers add that ambiguity tolerance may even be more vital in the early stages; however, this issue remains beyond the scope of this article).

Not surprisingly, both studies show that the strategies used by the GLLs and the 'less successful' learners may vary and may be utilized in differing ways, which can, among other factors, help to explain their differential language learning success. This finding has often been mentioned by other researchers as well (see, for example, Wenden, Rubin 1987; Oxford, 1989, 1990; Ellis, Sinclair, 1989; O’Malley, Chamot, 1990; Wenden, 1991; Droździał-Szelest, 1997; Cohen, 1998). In fact, 'good' language learners' enhanced technical know-how on how to learn foreign languages may explain their frequent use of metacognitive strategies and, among other factors which are not discussed in this article (e.g. aptitude, attitudes, motivation), lie behind their greater learning success. Oxford and Ehrman (1995) also report that persistent, orderly, methodical, planning, and systematic users of varied metacognitive strategies tend to be better educated. Additionally, the studies lend support to the claim that GLLs tend to be better users of cognitive strategies; they often make use of deeper data processing and semantic association techniques, which in turn may produce longer-lasting learning results (Oxford, Ehrman, 1995). It appears worth noting that in Oxford and Ehrman's 1995 study, highest proficiency levels, measured by the end-of-training scores, were found to be correlated with the use of cognitive strategies; the researchers noticed that the students who applied the strategies more often were also more persistent and better educated, had richer language learning experience, and saw themselves as intellectual rather than pragmatic.

Furthermore, the studies presented in this article showed that the GLLs tended to resort to some compensation strategies more frequently; it must be added that classroom observation as well as semiformal and informal interviews indicated that the GLLs experimented with the target language more willingly and, searching for meaning, they got more actively engaged in practice situations, which is also reported in other studies on the topic (see, for example, Stern, 1975). Nevertheless, not only these studies, but also Ehrman and Oxford's research (1989; 1990a, 1990b; 1995), confirmed that 'less successful', or lower aptitude, learners may also resort to compensation strategies relatively often. Thus, what may differentiate the two subgroups may lie in the ways in which they tend to use the strategies (e.g. Oxford and Ehrman found that their GLLs utilized more affective strategies, especially Positive Self-talk, to encourage themselves to activate more compensation strategies). Moreover, their motives may be somewhat different since, for example, the GLLs in both studies tended to employ paraphrasing or circumlocution more frequently to add extra clarity to their messages, while the 'less successful' subjects usually wished to quickly overcome problems in communication resulting from their inadequate L2 knowledge. Thus, they more often resorted to choosing a familiar topic, changing the topic of a conversation, or avoiding communication. Finally, in 1975 Rubin noted that GLLs might employ memory strategies more frequently and do so more effectively; however, these studies did not produce strong support for this claim 
since the 'less successful' students and the GLLs in Study A activated them in a comparable manner, while in Study B the former used memory strategies more frequently than the latter.

The differences found in the GLLs' and the 'less successful' learners' use of affective strategies in Study A and Study B were the least noticeable; in fact, the results were quite uniform. There could be various reasons for this. To start with, GLLs may somehow naturally and skillfully manage the affective, or emotional and motivational, demands of language learning more effectively than the 'less successful' learners and, therefore, they might not have to be fully aware of their application of affective strategies. This could also be associated with certain individual features that GLLs typically have, especially risk-taking, ambiguity tolerance, and readiness to make a fool of oneself in order to communicate and learn from communication (cf. Rubin, 1975). As Rubin and Thompson (1982, cited in Brown, 1994, pp.191-192) explain, GLLs "learn to live with uncertainty by not getting flustered (...), [they also] make errors work for them and not against them (...), learn certain tricks that help to keep conversations going, [and] learn certain production strategies to fill in gaps in their own competence"; also Naiman et al. $(1978,1996)$ stress that GLLs realize that language learning may be affectively difficult and are able to cope with such difficulties. Furthermore, this may also be linked to the subjects' age and maturity level, since adults tend to be more concerned about planning and academic learning strategies and less interested in affective and social strategy use, which class discussions and interviews with the subjects confirmed, and which the literature also shows (e.g. Stern, 1983). On the other hand, both subgroups might not have developed their affective strategies sufficiently well and, in consequence, underused them. In fact, as their answers to particular SILL questions indicated, their repertoires of affective strategies were not varied; most of the subjects applied one or two strategies more regularly and admitted that they did not employ or even know some of the strategies in this category.

Finally, the most noticeable discrepancy, on the other hand, can be noticed in the use of social strategies by the subjects in Study A and Study B. In fact, many researchers agree that GLLs like learning, cooperating, empathizing with others, and asking questions. However, in Study A the frequencies of social strategy use by both the GLLs and the 'less successful' subjects were classified as lower medium and low, though the rates recorded in the GLL subgroup were slightly higher. It must be noted that during class discussions and interviews the subjects repeatedly stressed their dislike for pair and group work, and voiced preferences for working individually and under the teacher's guidance. Interestingly, in Study B both subgroups used social strategies with upper medium and lower high frequencies. It seems that in order to explain such discrepancies, the time difference, or the passage of time, between the two research studies must be taken into account. It appears that the growing popularity of the learnercentered teaching methodology which promotes cooperation, group work and pair work, as well as project-based and task-based assignments, and other collaborative learning tasks used nowadays not only in foreign language classrooms, but also in other school subjects might have influenced the Sample B students' social skills and social learning preferences, common forms of work, and strategy choices as a result.

In fact, it must be emphasized that Study A was conducted in the academic year 2003/2004 and Study B was carried out more than 10 years later, in 2015. Teaching methodologies, teaching and learning conditions, and in particular opportunities for foreign language learning and use before and after Poland's accession to the European Union in 2004 have changed significantly, especially at primary school levels, and also at secondary and tertiary levels of education. Thus, the nature of the learner's language learning experiences has also changed. New possibilities of building personal foreign language learning experience via the use of modern information technologies, interactive whiteboards, online practice, social networking, and access to varied digital resources, educational apps, iTutor programmes and iTools have been created in the classroom and beyond it. Opportunities for travelling, visiting and studying in other countries, as well as communicating with other users of English, both native and non-native, have also expanded. Undoubtedly, such solutions may help today's language learners develop social skills and strategies, as well as enrich their individual repertoires of varied strategies for language learning and use, contributing to greater learner autonomy.

\section{Conclusions and implications}

The issues discussed in this series of three articles, concerned with what both teachers and learners can learn from 'good' language learners, successful and unsuccessful use of learning strategies, and learner individual differences, are closely connected with the vital pedagogical task of educating self-regulated, autonomous or independent, language learners able to face the demands of today's dynamically changing world. As many experts agree, such learners are knowledgeable about how to learn effectively and able to plan and re-plan, organize, manage, control, and evaluate their own learning efficiently. The results of a number of research studies presented in the three articles allow us to postulate that those who succeed, or 'good' language learners, seem to possess certain individual characteristics which may be associated with language learning success. Moreover, they tend to activate varied strategies which can facilitate the complex task of second/foreign language learning. In fact, as many researchers notice, 'good' language learners appear to be better able to select and 
employ effective strategies for language learning and use, which they apply appropriately, considering the nature of the task at hand and in response to their own learning preferences. What seems to be the key to understanding their language learning success are unique combinations of personality traits, cognitive/learning styles, and strategies for language learning and use (Ehrman, Oxford, 1995; Ehrman, Leaver, Oxford, 2003; Griffiths, 2008).

About thirty years ago Rubin (1987) postulated that the strategies of 'good' language learners might be taught to less successful ones. As numerous intervention studies conducted so far prove, planned and directed strategy instruction, especially in its explicit or fully-informed forms, and purposeful strategy integration into regular language learning and content subject courses can help learners develop their metacognition and enrich self-awareness. This in turn is necessary to focus, understand, and reflect upon one's own learning processes and oneself as a language learner. What is more, intervention studies prove that less successful students can learn how to use strategies or tactics of different types appropriately, depending on the purpose of a language learning task, and in response to individual preferences. In this way, by learning to learn, these learners can make their task "easier, faster, more enjoyable, more self-directed, more effective, and more transferable to new situations" (Oxford, 1990, p. 8).

Self-knowledge, or self-awareness, seems to be of key importance to strategically self- regulated learners since, as Oxford (2011) stresses, participating actively in their learning, they can regulate their own cognitive and affective states, as well as behaviour in particular situations and circumstances; they can control their beliefs, manage the self and change environmental conditions. As numerous research studies confirm, age, personality traits, cognitive/learning styles, as well as personal opinions and beliefs may have an influence on learning decisions, strategy choices, and individual development of idiosyncratic repertoires of effective strategic behaviours which can help learners to cope with both intellectual and psychological, or socio-affective, demands of second/foreign language learning.

Learning to learn (more) effectively and becoming a (more) self-regulated and self-aware learner lies within the scope of learner strategy training, also known as Strategies-Based Instruction (SBI) or Styles-and-Strategies-Based Instruction (SSBI). As experts often stress, such instruction should preferably be interdisciplinary; thus, it should become an integrated part of not only language teaching/learning programmes, butalso syllabuses of each school subject taught at primary and secondary, as well as tertiary levels. By experimenting with the same and different strategies across different subjects, learners can experience and understand how selected learning strategies can be activated with, and transferred to, varied learning tasks and see why strategies of different types are vital in many learning contexts and situations.

\section{References:}

1. Abraham, R., Vann, R. (1987). Strategies of two language learners: a case study. In: A. Wenden, Rubin, J. (eds.), Learner Strategies in Language Learning (pp. 85-102). Cambridge: Prentice Hall.

2. Brown, H. D. (1994). Teaching by Principles. An Interactive Approach to Language Pedagogy. White Plains, NY: Prentice Hall Regents.

3. Chamot, A. U. (2004). Issues in Language Learning Strategy Research and Teaching. Electronic Journal of Foreign Language Teaching, 1(1), 14-26. Accessed at: http://www.google.pl/webhp?nord=1\&gws_ rd=cr\&ei=DRtGVe2AEqSxygP6rIEQ\#nord=1\&q=e-flt.nus.edu.sg\%2Fv1n12004\%2Fchamot.pdf

4. Chamot, A. U., Barnhardt, S., El-Dinary, P. B., Robbins J. (1999). The Learning Strategies Handbook. White Plains, NY: Addison Wesley Longman.

5. Cohen, A. D. (1998). Strategies in Learning and Using a Second Language. New York: Addison Wesley Longman.

6. Cohen, A. D. (2010). Focus on the Language Learner: Styles, Strategies and Motivation. In: N. Schmitt (ed.), An Introduction to Applied Linguistics ( $2^{\text {nd }}$ ed.) (pp. 161-178). London: Hodder Education.

7. Cohen, A. D., Macaro, E. (eds.). (2007). Language Learner Strategies: Thirty Years of Research and Practice. Oxford: Oxford University Press.

8. Dąbrowska, M. (2008). Strategies of Foreign Language Learning and Use: the Educational Value of Strategy Training in Teaching English to Adult Learners. Unpublished Ph.D. dissertation written under the supervision of Professor Hanna Komorowska. Warsaw: Warsaw University, The Institute of English Studies.

9. Dąbrowska, M. (2011). Cel kształcenia językowego - nauczyć się, jak się uczyć. In: H. Komorowska (ed.), Nauka języka obcego w perspektywie ucznia. Podręcznik akademicki (pp. 78-103). Warszawa: Oficyna Wydawnicza Łośgraf.

10. Droździał-Szelest, K. (1997). Language Learning Strategies in the Process of Acquiring a Foreign Language. Poznań: MOTIVEX.

\footnotetext{
See, for example, Droździał-Szelest, 1997; Cohen, 1998; Chamot, Barnhardt, El-Dinary, Robbins, 1999; Chamot, 2004; Cohen, Macaro, 2007; Dąbrowska, 2008; Oxford, 2011.
} 
11. Ehrman, M., Oxford, R. L. (1989). Effects of sex differences, career choice, and psychological type on adult language learning strategies. The Modern Language Journal, 73(1), 1-13. https://doi.org/10.1111/j.1540-4781.1989.tb05302.x

12. Ehrman, M., Oxford, R. L. (1990a). Adult language learning styles and strategies in an intensive training setting. Modern Language Journal 74(3), 311-327. https://doi.org/10.1111/j.1540-4781.1990.tb01069.x

13. Ehrman, M., Oxford, R. L. (1990b). Effects of sex differences, career choice, and psychological type on adults' language learning strategies. The Modern Language Journal 73(1), 1-13. https://doi.org/10.1111/j.1540-4781.1989.tb05302.x

14. Ehrman, M., Oxford, R. L. (1995). Cognition plus: Correlates of adult language proficiency. Modern Language Journal 79, 67-89. https://doi.org/10.1111/j.1540-4781.1995.tb05417.x

15. Ehrman, M., Leaver, B. L, Oxford, R. L. (2003). A brief overview of individual differences in second language learning. System, 31(3), 313-330. https://doi.org/10.1016/S0346-251X(03)00045-9

16. Ellis, G., Sinclair, B. (1989). Learning to Learn English: A course in Learner Training. Cambridge: Cambridge University Press.

17. Janowska, I. (2003). Nauczmy uczniów się uczyć - o autonomii. Języki Obce w Szkole, 3, 30-38.

18. Naiman, N., Frohlich, M., Stern, H. H., Todesco, A. $(1978,1996)$. The Good Language Learner. The Ontario Institute For Studies in Education Modern Languages in Practice: 4. Multilingual Matters.

19. O’Malley, J. M., Chamot, A. U. (1990). Learning Strategies in Second Language Acquisition. Cambridge: Cambridge University Press.

20. Oxford, R. L. (1989). Use of language learning strategies: a synthesis of studies with implications for strategy training. System, 17(2), 235-247. https://doi.org/10.1016/0346-251X(89)90036-5

21. Oxford, R. L. (1990). Language Learning Strategies: What Every Teacher Should Know. Boston: Heinle and Heinle Publishers.

22. Oxford, R. L. (2002). Language Learning Strategies in a Nutshell: Update and ESL Suggestions. In: J. C. Richards, W. A. Renandya (eds.), Methodology in Language Teaching (pp. 124-132). Cambridge: Cambridge University Press.

23. Oxford, R. L. (2011). Teaching and Researching Language Learning Strategies. Harlow: Pearson Education.

24. Oxford, R. L., Ehrman, M. (1995). Adults' Language Learning Strategies in an Intensive Foreign Language Programme in the United States.System 23(3), 359-386. https://doi.org/10.1016/0346-251x(95)00023-d

25. Reid, J. (1995). Learning Styles in the ESL/EFL Classroom. Boston: Newbury House.

26. Rubin, J. (1975). What 'the good language learner' can teach us. TESOL Quarterly, 9(1), 41-51. https://doi.org/10.2307/3586011

27. Rubin, J. (1987). Learner strategies: Theoretical assumptions, research, history, and typology. In: A. L. Wenden, J. Rubin (eds.), Learner Strategies in Language Learning (pp. 15-30). Cambridge: Prentice Hall.

28. Rubin, J., Thompson, I. (1982). How to Be a More Successful Language Learner. Boston: Heinle \& Heinle.

29. Stern, H. H. (1975). What can we learn from the good language learner? Canadian Modern Language Review 31(2), 304-318.

30. Stern, H. H. (1983). Fundamental Concepts of Language Teaching. Oxford: Oxford University Press.

31. Tanner, R., Green, C. (1998). Tasks for Teacher Education. Harlow: Longman.

32. Wenden, A. L. (1991). Learner Strategies for Learner Autonomy. Cambridge: Prentice Hall.

33. Wenden, A. L., Rubin J. (eds.). (1987). Learner Strategies in Language Learning. Cambridge: Prentice Hall.

34. Wilczyńska, W. (ed.). (2002). Autonomizacja w dydaktyce języków obcych. Doskonalenie się w komunikacji ustnej. Poznań: Wydawnictwo Naukowe UAM. 